\title{
Physiological pituitary hyperplasia misinterpreted and treated as lymphocytic hypophysitis
}

\author{
Sugata Narayan Biswas, Himanshu Barman, Tuhin Subhra Sarkar, \\ Partha Pratim Chakraborty
}

Department of Medicine, Midnapore Medical College and Hospital, Midnapore, West Bengal, India

Correspondence to Dr Partha Pratim Chakraborty, docparthapc@yahoo.co.in

Accepted 17 July 2018
D Check for updates

(c) BMJ Publishing Group Limited 2018. No commercial re-use. See rights and permissions. Published by BMJ.

\begin{tabular}{|l|}
\hline To cite: Biswas SN, \\
Barman H, Sarkar TS, et al. \\
BMJ Case Rep Published \\
Online First: [please \\
include Day Month Year]. \\
doi:10.1136/bcr-2018- \\
225996 \\
\hline
\end{tabular}

\section{DESCRIPTION}

A 19-year-old nulliparous eumenorrhoeic woman diagnosed with bilateral serous retinal detachment was referred for incidentally detected enlarged pituitary gland, seen on MRI of orbit. A focused MRI documented diffuse, symmetric enlargement of the pituitary gland having a convex superior surface abutting the optic chiasm $(11.4 \mathrm{~mm}$ in antero-posterior $\times 16.9 \mathrm{~mm}$ in transverse $\times 9.3 \mathrm{~mm}$ in height) with marked homogeneous gadolinium enhancement with a thickened, non-tapering stalk (3.5 $\mathrm{mm}$ at infundibulum) and a conspicuous eutopic posterior pituitary bright spot (figure 1). A comprehensive work-up remained unremarkable

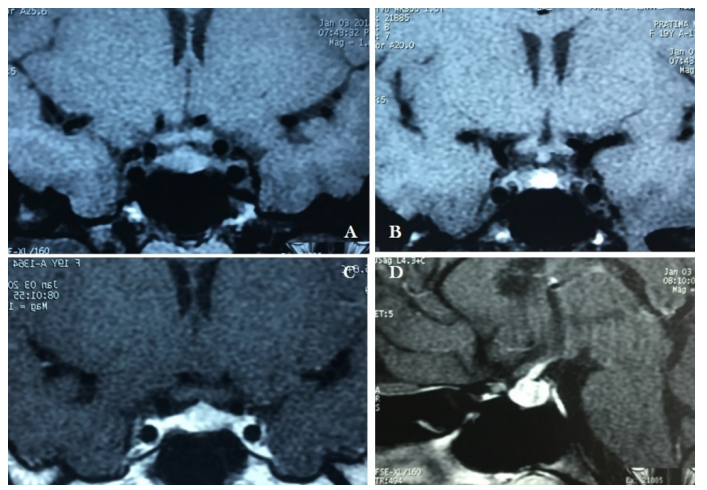

Figure $1 \mathrm{MRI}$ at initial presentation showing diffuse enlargement of pituitary (A), thickened stalk with conspicuous bright spot (B) and intense homogenous contrast enhancement $(C, D)$ of both pituitary and stalk.

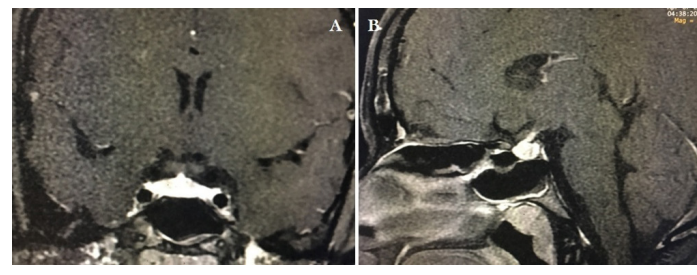

Figure 2 Post-contrast MRI at 1 year follow-up showing enlarged pituitary (A) with intense and homogenous contrast enhancement with a thickened stalk (B). The appearance is unchanged from the initial MRI.

(table 1). In view of symmetric, enlarged pituitary demonstrating intense homogeneous contrast enhancement and a thickened $(>2-3 \mathrm{~mm}$ thickness is considered pathological), non-tapering pituitary stalk in this non-pregnant individual, a diagnosis of lymphocytic hypophysitis (LH) was considered, after ruling out the other possible differential diagnosis. Pulse therapy with intravenous methylprednisolone was initiated followed by maintenance therapy with daily prednisolone gradually tapered over 12 weeks. However, serial MRI 4 days following therapy, at 6 months and a year later (figure 2), failed to demonstrate any significant reduction of pituitary or stalk size, necessitating a review of diagnosis.

Incidental pituitary enlargement is a frequent cause of referral to endocrinologists. The pituitary gland exhibits wide variations in size and shape across different age, sex and ethnicity cohorts.

\begin{tabular}{|c|c|c|c|}
\hline Parameter & At presentation & After 12 months & Reference range \\
\hline Cortisol (08:00) & 15.68 & 11.6 & $05-25 \mu \mathrm{g} / \mathrm{dL}$ \\
\hline $\begin{array}{l}\text { Cortisol after overnight } 1 \mathrm{mg} \text { dexamethasone } \\
\text { suppression test }\end{array}$ & 1.2 & & $<1.8 \mu \mathrm{g} / \mathrm{dL}$ \\
\hline Thyroid-stimulating hormone & 0.79 & 0.9 & $0.34-4.25 \mathrm{mlU} / \mathrm{L}$ \\
\hline FT4 & 1.1 & 1.4 & $0.7-1.24 \mathrm{ng} / \mathrm{dL}$ \\
\hline T3 & 102 & 98 & $77-135 \mathrm{ng} / \mathrm{dL}$ \\
\hline Prolactin & 13.86 & 15.04 & $1.9-25 \mathrm{ng} / \mathrm{mL}$ \\
\hline Insulin like growth factor (IGF)1 & 224 & & $138-442 \mathrm{ng} / \mathrm{mL}$ \\
\hline$\beta$ human chorionic gonadotropin (HCG) & 1.2 & & $<5 \mathrm{mlU} / \mathrm{mL}$ \\
\hline Cerebrospinal fluid (CSF) appearance & Colourless, clear & & \\
\hline CSF cell count & 2 & & $0-5$ mononuclear cells $/ \mu \mathrm{L}$ \\
\hline CSF protein & 30 & & $15-50 \mathrm{mg} / \mathrm{dL}$ \\
\hline CSF angiotensin converting enzyme (ACE) & $<0.1$ & & $0.0-2.5 \mathrm{U} / \mathrm{L}$ \\
\hline CSF adenosine deaminase (ADA) & 0.3 & & $0-1.5 \mathrm{U} / \mathrm{L}$ \\
\hline CSF PCR for Mycobacterium tuberculosis & Not detected & & \\
\hline CSF $\beta$ HCG, quantitative & 0.1 & & $0-3 \mathrm{IU} / \mathrm{L}$ \\
\hline
\end{tabular}


Physiological pituitary hypertrophy (pituitary height $\geq 9 \mathrm{~mm}$ ) is observed during puberty and pregnancy, in young women and after menopause. ${ }^{1}$ In healthy women between 15 and 30 years of age, the height of the pituitary varied from 3 to $9 \mathrm{~mm}$, as observed in neuroradiological series. ${ }^{1}$ A population study from India observed a mean pituitary height of $6.0( \pm 1.6 \mathrm{SD}) \mathrm{mm}$ in females belonging to 11-20 years of age. ${ }^{2}$ Pathological pituitary hypertrophy may occur in long-standing untreated end organ insufficiency with loss of negative feedback (primary hypothyroidism, primary hypogonadism), hypothalamic or neuroendocrine tumours secreting excess trophic hormones [growth hormone releasing hormone $(\mathrm{GHRH})$, corticotropin releasing hormone $(\mathrm{CRH})]$ and a number of inflammatory or infiltrative diseases (lymphocytic and granulomatous hypophysitis, sarcoidosis, haemochromatosis, amyloidosis, Langerhans cell histiocytosis, Wegener's granulomatosis), infective (tuberculosis) and neoplastic (germinoma, lymphoma, leukaemia, metastatic carcinoma) disorders. Underlying tuberculosis, sarcoidosis and central nervous system germinoma were excluded with certainty in this woman with appropriate tests. Central serous retinopathy, rarely, has been known to be associated with Cushing's disease. Serous retinal detachment with subretinal fluid accumulation, a variant of central serous retinopathy, along with pituitary enlargement with thickened stalk in this woman, necessitated a thorough evaluation. Since corticosteroids have a beneficial role in early stages of $\mathrm{LH}^{3}$ high-dose glucocorticoids were administered. Learning from our errors, we conclude this patient to be a case of physiological hypertrophy of the pituitary gland $(\mathrm{PH})$. Without a pituitary biopsy the diagnosis of $\mathrm{PH}$, although highly likely in this woman, remains presumptive. Since the duration of persistent peripubertal pituitary hyperplasia is unknown and data on epidemiology, diagnosis or management of $\mathrm{PH}$ are scarce, and a pituitary biopsy facilitating a tissue diagnosis remains elusive in routine clinical practice, the diagnosis of $\mathrm{PH}$ is largely clinico-hormono-radiological. Thus, pituitary enlargement (pituitary height $\geq 9 \mathrm{~mm}$, or greater than that predicted by age, gender and ethnicity matched values, when available) with a normal hormonal assessment (absence of hyperprolactinaemia or diabetes insipidus in particular) and gland homogeneity on MRI (plain and contrast) with a conspicuous posterior pituitary bright spot should also be considered as normal pituitary hypertrophy to avoid therapeutic misadventures.

\section{Learning points}

- Pituitary gland dimensions in normal individuals are largely influenced by age, gender and ethnicity.

- Pituitary height ranging from 3 to $9 \mathrm{~mm}$ with anteroposterior and transverse diameter of $10-14 \mathrm{~mm}$ is considered normal.

- The pituitary stalk normally is widest superiorly and tapers inferiorly measuring $3.5 \mathrm{~mm}$ near median eminence, $2.9 \mathrm{~mm}$ near its midpoint and $1.9 \mathrm{~mm}$ at its insertion to the pituitary.

- Physiological pituitary hypertrophy is observed during puberty and pregnancy, in young women and after menopause.

- The duration of persistence of physiological hypertrophy following puberty is not known.

- Minimal pituitary enlargement (height $\geq 9 \mathrm{~mm}$, or greater than that predicted by age, gender and ethnicity matched values, when available) with a normal hormonal assessment (absence of hyperprolactinaemia, cortisol deficiency or diabetes insipidus in particular) and gland homogeneity on MRI (plain and contrast) with a conspicuous posterior pituitary bright spot should be considered as normal pituitary hypertrophy.

- Correct identification of pituitary hypertrophy obviates the need of unnecessary therapeutic interventions as it rarely progresses.

Contributors SNB, HB, TSS and PPC were involved in patient management. SNB and HB did the literature search and wrote the manuscript. PPC finalised the draft.

Funding The authors have not declared a specific grant for this research from any funding agency in the public, commercial or not-for-profit sectors.

Competing interests None declared.

Patient consent Obtained.

Provenance and peer review Not commissioned; externally peer reviewed.

\section{REFERENCES}

1 Chanson P, Daujat F, Young J, et al. Normal pituitary hypertrophy as a frequent cause of pituitary incidentaloma: a follow-up study. J Clin Endocrinol Metab 2001;86:3009-15.

2 Yadav P, Singhal S, Chauhan S, et al. MRI Evaluation of size and shape of normal pituitary gland: age and sex related changes. J Clin Diagn Res 2017;11:TC01-4.

3 Nishioka H, Ito H, Fukushima C. Recurrent lymphocytic hypophysitis: case report. Neurosurgery 1997;41:684-6.

Copyright 2018 BMJ Publishing Group. All rights reserved. For permission to reuse any of this content visit

http://group.bmj.com/group/rights-licensing/permissions.

BMJ Case Report Fellows may re-use this article for personal use and teaching without any further permission.

Become a Fellow of BMJ Case Reports today and you can:

- Submit as many cases as you like

- Enjoy fast sympathetic peer review and rapid publication of accepted articles

- Access all the published articles

- Re-use any of the published material for personal use and teaching without further permission

For information on Institutional Fellowships contact consortiasales@bmjgroup.com

Visit casereports.bmj.com for more articles like this and to become a Fellow 